\title{
ASSESSMENT AND BIOACCUMULATION OF CU AND PB IN THE BIOTA (TUBER PLANT) IN A MINING DISTRICT OF AMEKA- ENYIGBA, ABAKALIKI MINING DISTRICT, SOUTHEASTERN NIGERIA: A COMPARATIVE STUDY
}

\author{
Onyeabor, Chinenye F. ${ }^{1}$; Ezeh, Hillary N. ${ }^{11}$, Anike, Luke O. ${ }^{111}$ \\ 1edeaninenye@esut.edu.ng \\ ${ }^{1,111}$ Enugu State University of Science and Technology, Agbani Enugu Nigeria \\ ${ }^{11}$ Ebonyi State University, Abakaliki Ebonyi State Nigeria.
}

\begin{abstract}
This research tries to compare two investigative approaches towards the accumulation of heavy metals of $\mathrm{Cu}$ and $\mathrm{Pb}$ in Ameka-Enyigbabiota. Both farmland soils and tuber plant (cassava roots) were obtained with the soil sample being oven dried at $104^{\circ} \mathrm{c}$,homogenized with mortar, pestle and sieved to obtain a greater surface area. The soils were thereafter sequentially digested to obtain extracts of exchangeable, reducible, organic and residual fractions of bioavailability studies. The cassava plants were obtained and hormogenized and digested with aqua regia. All the extracts were analyzed with the AA sens Atomic Absorption Spectrophotometer. The results revealed that the bioavailable $\mathrm{Cu}$ in the study exceeded the exchangeable to the reducible but was still within the acceptable limit both in the bioavailable $\mathrm{Cu}$ in soil and Plant uptake; whereas $\mathrm{Pb}$ which was within the exchangeable exceeded the maximum acceptable limit in both the bioavailable $\mathrm{Pb}$ and the plant uptake. This level of $\mathrm{Pb}$ if not checkmated and controlled, could result to lead poisoning in Enyigba-Ameka within a short time span.
\end{abstract}

\section{Introduction}

The total heavy metal in a polluted soil does not imply the available heavy metal accessible to the biosphere; hence the emergence of bioavailability studies to evaluate and properly define the actual heavy metals resulting to pollution in any geochemical system. The level of pollution is determined by the proportion of the metal that is bioavailable (Traina and La Perche 1999, Kim and Fergussion 1991 and Kheborian and Bauer 1987). The U.S Navy and Marine Corps Guide (2000) opined that for a proper evaluation of ecological bioavailability studies to be conducted, three different approaches are considered necessary:

i. Evaluating direct exposures to the available fraction of metals present in the environment media (e.g. sediment or soil).

ii. Evaluation of bioaccumulation directly from the environmental media (food chain, plants) and

iii. Evaluation of uptake from ingestion of food.

Several bioavailability studies have emphasized their studies on the first exposure on soil and underestimating the second and third approaches due to some challenges related to inter disciplinary research especially in most developing countries. This research work is aimed at evaluating bioaccumulation directly from the plant media cultivated in the area comparing it with result obtained by sequentially extracted media of the soil; thus, having the first and second approaches applied. 


\section{Previous work}

Over the years the mining effects and general environmental truncation of Enyigba- Ameka has been of major concern. Several researchers have raised issues of pollution concern in Enyigba-Ameka mining town of Abakiliki. These includes the likes of Onyeabor and Nwatarali 2017, Nnabo et a.1 2011, Eze et al. 2007 and Obasi and Akudinobi (2015). High concentration of heavy metalsexhibits chronic toxicity or carcinogenicity as well as fatality (Blaylock and Huang 2000) if bioavailable. This is because it has been proved that total concentration of metals in soils does not equal its bioavailability (Menzies et al. 2007 and Oyeyiola et al 2010).

Mehra et al. (1999) observed that the $\mathrm{Cu}$ and $\mathrm{Cd}$ contaminated soil of Staffordshire U.K. which had lower concentration of $\mathrm{Cd}$ compared to $\mathrm{Cu}$ ended up being about three times more readily available than $\mathrm{Cu}$. This was due to the non-bioavailable form of $\mathrm{Cu}$ and its mobility rate in Staffordshire. The speciation/chemical form also contribute to its bioavailability and plant transfer factor because not all states of the heavy metal are easily absorbed by plants or even carcinogenic when ingested into animal or human body (NEPI, 2000). Olayinka et al. (2011) observed that planting of vegetable samples caused a change in the soil-heavy metal in soilsand that plant uptake and accumulation is dependenton plant type. Ezeh et al. (2007) also observed that tubers have higher tendency of $\mathrm{Cu}$ and $\mathrm{Zn}$ absorption transfer hence the circulation of these metals in the biosphere in the Enyigba. Chojnacka et al. (2004) opined in his work that only bioavailable elements were transferred to plants using citrate solution extractant; and that the statistical value of the element content extracted with ammonium citrate in soil was equal to that absorbed by the selected plants used for investigation. Bioavailability and bioaccumulation studies are better done with three standard approaches by U.S Navy and Marine Corp Guide (2000).

\section{The Geology}

The study area is situated within the lead-zinc deposit belt of Nigeria (Mamah et al. 2000). It is situated about $14-15 \mathrm{~km}$ North of Abakaliki town and overlies the Abakaliki Anticlinorium of the Southern Benue Trough. Enyigba-Ameka and environs is underlain by the Abakaliki Formation which comprises of the shale, sandstone and siltstone units. The Abakaliki Shale is fissile, indurated, pyritic, brown to dark grey in colour especially around the mineralized veins. The shales are fractured, faulted and mineralized with $\mathrm{Pb}-\mathrm{Zn}$ veins in association with minor Cu.Mineralization in Enyigba-Ameka occurs along a narrow belt of approximately 30 to $50 \mathrm{~km}$ wide and extends for about 560 to $600 \mathrm{~km}$ length of the Benue Trough streching from Ishiagu, Abakaliki, Benue, Nasarawa, Plateau, Bauchi, Taraba and Adamawa states. The study area is overlain by long stretches of indurated shale which ranges from about 10 to $15 \mathrm{~km}$. Theinduration of the shales increases toward Abakiliki town and Ezzagu where the intrusives and the extrusives occurs respectively, thus the quarry of the shales for construction and aesthetic purposes. The geologic map of the study area is exemplified in fig.1.0. 


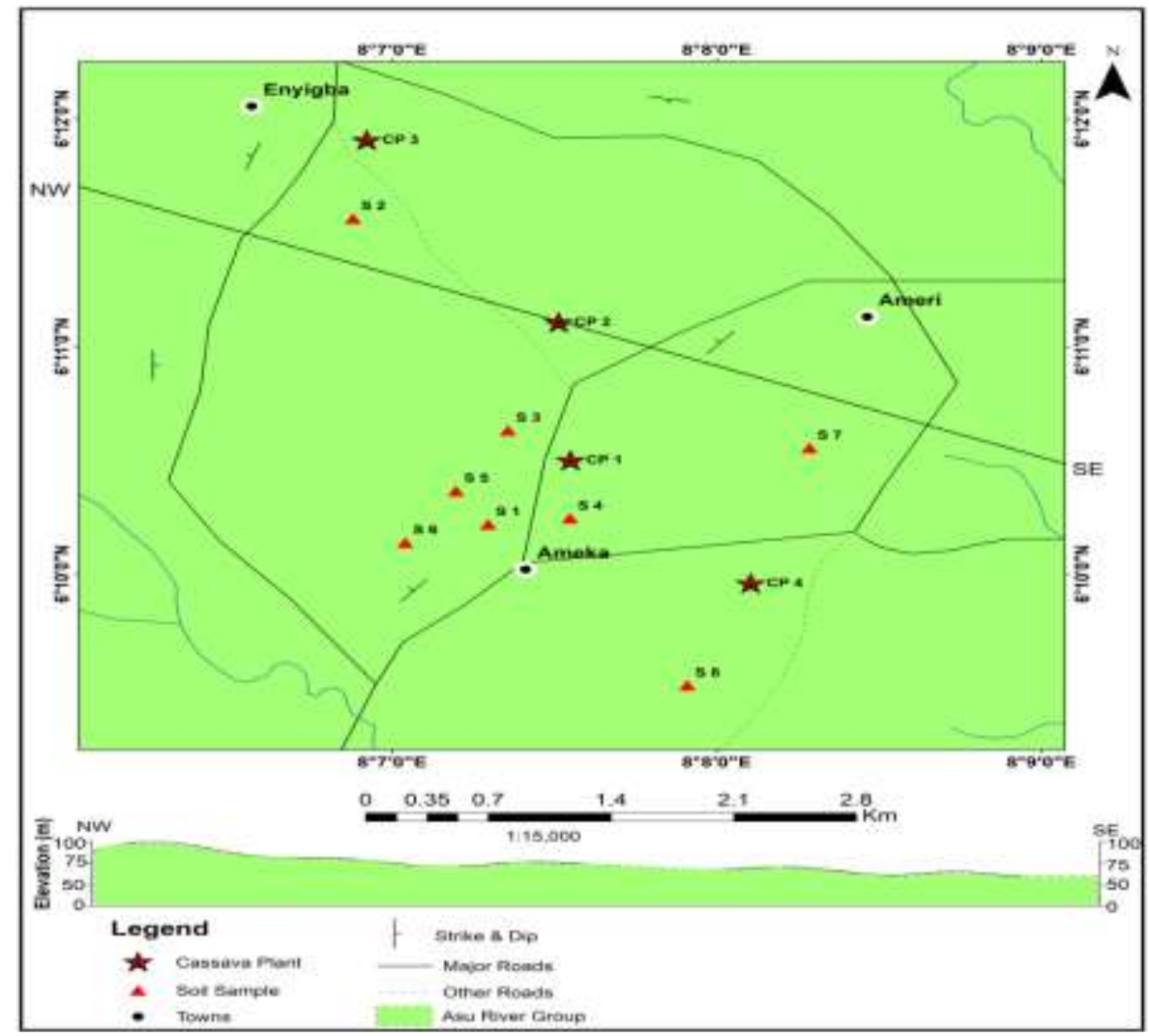

Fig.1.0 The Geologic map of Ameka- Enyigba, Southeast Nigeria

\section{Materials and Method}

A total of eight (8) farm land soil samples were obtained with a hand auger at a depth of $1 \mathrm{~cm}$ to $15 \mathrm{~cm}$ and the sampling points shown in fig.2.0. The samples were oven dried at a temperature of $104^{\circ} \mathrm{C}$ for three hours. The dried samples were crushed homogenized with mortar and pestle and then sieved with 200 micron mesh sieve in order to create a good surface area and adsorption as seen majorly in clay minerals, shale and organic matter (Kabata-Pendias, 2011). The extracts were sequentially extracted using various reagents and procedures at various stages with the BCR method (Tokalio ${ }^{-G l u}$,et.al.2003) on the soil. The four stages of the sequential extraction were applied thus;

The exchangeable metals (readily available):1.00g of the sieved oven dried soil sample was weighed into a $40 \mathrm{ml}$ of $0.11 \mathrm{~mol}^{-1}$ acetic acid using a conical flask and shared with an orbital shaker(model KJ201BS) for 16 hours continuously at 350rpm (room temperature). The extract was separated from the solid by the use of centrifuge for 20 minutes. The extract was decanted into a $100 \mathrm{ml}$ polyethylene bottle for analysis. The soil residue was washed by adding $20 \mathrm{ml}$ of distilled water and filtered within 10 to 20 minutes.

Metals Bound to Iron and Manganese (potentially available): The metals bound to Iron and manganese were obtained by adding $40 \mathrm{ml}$ of $0.1 \mathrm{~mol} \mathrm{~L}^{-1}$ of hydroxyl ammonium chloride into the residue from the first fraction. This was adjusted to $\mathrm{pH} 2$ with $2 \mathrm{~mol} \mathrm{~L}^{-1}$ of nitric acid. This solution was centrifuged for 20mins after shaking for 16 hours continuously at room temperature at $350 \mathrm{rpm}$. The extract was decanted into a $100 \mathrm{ml}$ polyethylene bottle and set for analysis using AAS. The residue was washed with $20 \mathrm{ml}$ of distilled water, shaken for 15 mins, centrifuged, decanted and the supernatant discarded.

Metals Bound to Organic Matter and Sulphides (potentially available):The residue from the second fraction was used for this stage. $10 \mathrm{ml}$ of $8.8 \mathrm{~mol} \mathrm{~L}^{-1}$ of hydrogen peroxide was added in small aliquots to the residue in a conical flask and shaken manually. This was sent into a 
water bath and raised to a temperature of $85^{\circ} \mathrm{C}$ and had the volume reduced to a few millimeters. Thereafter, a second aliquot of $10 \mathrm{ml}$ of hydrogen peroxide and shaken for few minutes. The solution was heated to near dryness before adding $50 \mathrm{ml}$ of $1.0 \mathrm{~mol} \mathrm{~L}^{-1}$ ammonium acetate solution and adjusted to $\mathrm{pH}$ of 2 with nitric acid. The solution was shaken for few minutes and centrifuged. The extract was separated from the residue for analysis while the residue was washed as described earlier.

Residual: The extraction/digestion of this last stage was done using aqua regia prepared in a ratio of $3 \mathrm{HCl}: \mathrm{HNO}_{3}$. The digestion was done by adding $6 \mathrm{ml}$ of distilled water into the residue before adding the aqua regia solution in a sequence of $15 \mathrm{ml}$ and $10 \mathrm{ml}$. Each of the sequence addition was followed by evaporation to near dryness using a water bath. Thereafter $2 \mathrm{ml}$ of $1 \mathrm{~mol} \mathrm{~L}^{-1}$ of $\mathrm{HNO}_{3}$ was added and the solution centrifuged in order separate the extract from the residue.

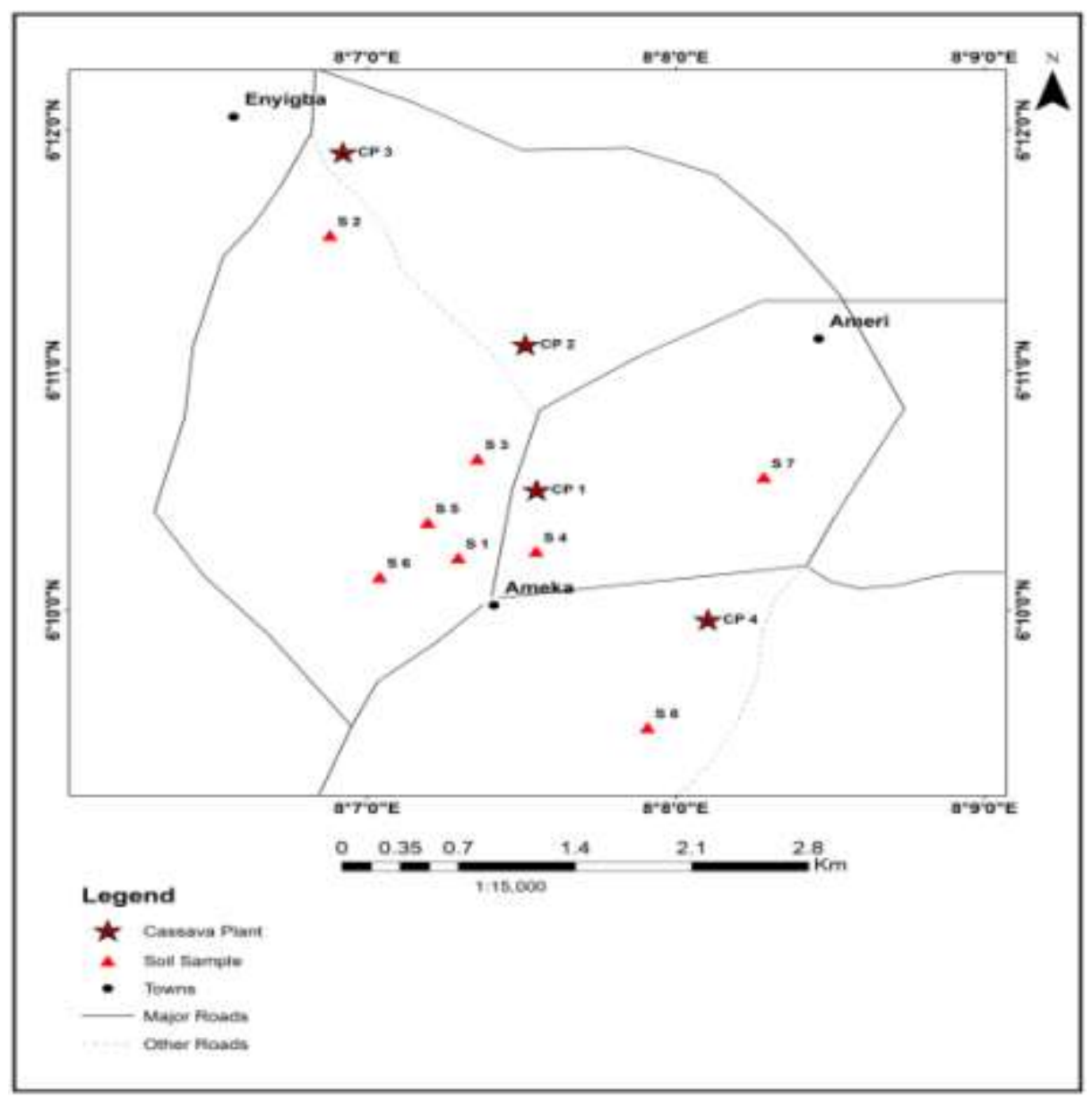

Fig. 2.0 The Geologic map of Ameka- Enyigba

All the extracts obtained were analyzed for heavy metal analysis using Sens A.A model of Atomic absorption Spectrophotometer (A.A.S) and the results obtained.

Cassava plant samples were obtained from the study area and shown in fig.2.0 The plant stems were obtained, crushed and homogenized and digested with aqua-regia reagent in order to extract the entire heavy metals of interest present in them. The obtained extracts were analyzed with same Sens A.A model of A.A.S. and the result shown in Table 2.0. 


\section{Result, Interpretation and Discussion}

The various fractions of $\mathrm{Cu}$ and $\mathrm{Pb}$ available to the biota (i.e. readily available, potentially available and the residue of the soil and stream sediments were obtained and the mean average values given in Table 1.0with its bar chart in fig.3.0. This shows the high value of $\mathrm{Pb}$ in the study area with its various sequential fractions higher than that of $\mathrm{Cu}$. The mean values of the cassava plant heavy metal bioaccumulation are given in Table 2.0

Table 1.0 Mean Average of $\mathrm{Cu}$ and $\mathrm{Pb}$ in Farm Land Soils of Enyigba-Ameka

\begin{tabular}{|c|c|c|}
\hline FRACTION & $\mathrm{Cu}(\mathrm{Mg} / \mathrm{Kg})$ & $\mathrm{Pb}(\mathrm{Mg} / \mathrm{Kg})$ \\
\hline $\begin{array}{c}\text { Exchangeable/carbonate/readily } \\
\text { available/bioavailable }\end{array}$ & 2.004 & 94.0604 \\
\hline $\begin{array}{l}\text { Reducible(iron/manganese oxides)/potentially } \\
\text { available }\end{array}$ & 3.159 & 70.531 \\
\hline $\begin{array}{l}\text { Oxidisable (organic substance and sulphides)/ } \\
\text { potentially available }\end{array}$ & 9.112 & 58.3689 \\
\hline Residue (aqua regia digestion) & 26.524 & 153.162 \\
\hline Total metal Present & 40.799 & 376.1223 \\
\hline
\end{tabular}

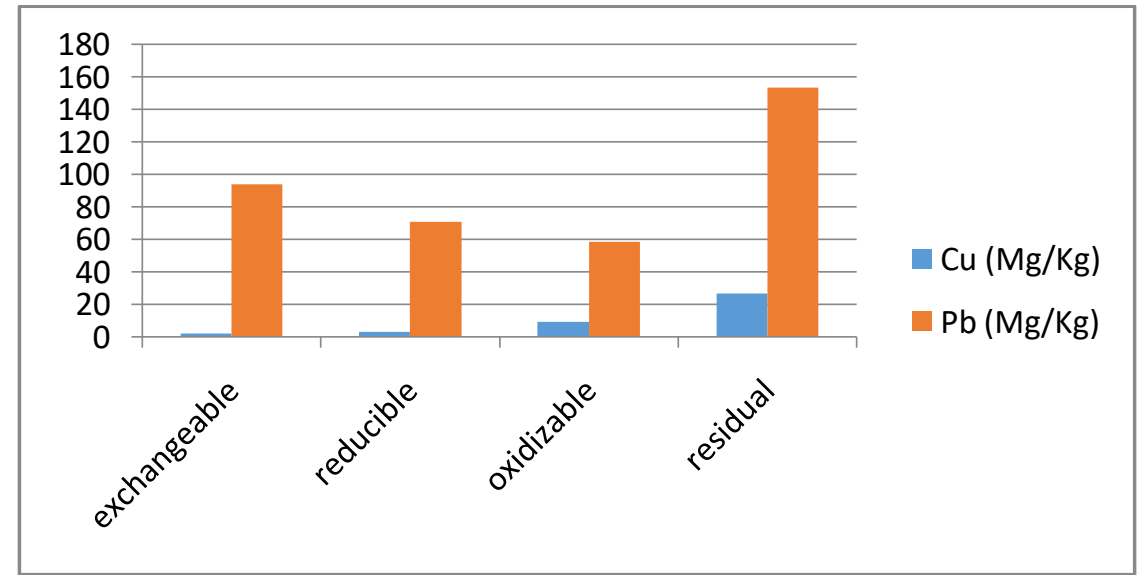

Fig.3.0 Distribution Chart of Sequentially extracted $\mathrm{Cu}$ and $\mathrm{Pb}$ of the F.L.

Table 2.0 Plant uptake values of $\mathrm{Cu}$ and $\mathrm{Pb}$ in Enyigba-Ameka

\begin{tabular}{|l|l|l|}
\hline Location & $\mathbf{C u}(\mathbf{m g} / \mathbf{k g})$ in Plant & $\mathbf{P b}(\mathbf{m g} / \mathbf{k g})$ in Plant \\
\hline Enyigba & 5.221 & 7.390 \\
\hline Ameka & 5.039 & 12.236 \\
\hline Mean Average & 5.13 & 9.813 \\
\hline
\end{tabular}

The total value of each of $\mathrm{Cu}$ and $\mathrm{Pb}$ are high compared to the exchangeable (Tab. 1.0) values which are readily available to the cassava plant for uptake and absorption. The result of the obtained heavy metals of $\mathrm{Cu}$ and $\mathrm{Pb}$ in cassava plant (tab.2.0) was compared with the result of the sequentially extracted soil samples (tab.3.0). The $\mathrm{Cu}$ uptake by the plants falls within the exchangeable and reducible values of $\mathrm{Cu}$ in the soils at 99.36\% (Equ.1.0). The accumulation of $\mathrm{Cu}$ into the reducible could be induced by the high mobility of $\mathrm{Cu}$, thus resulting to the fast move of the exchangeable which resulted to the reducible fraction being very available for plant uptake. The entire exchangeable and reducible fraction are taken by cassava plants. This is not same with $\mathrm{Pb}$ which has very low mobility rate. The value of plant 
uptake of lead also falls within the soil exchangeable limit for $\mathrm{Pb}$ with a lower margin unlike the $\mathrm{Cu}$ result. This could be associated with the passive root system described by Hughes et al.(1930) in Thornton (1983). $25 \%$ of $\mathrm{Pb}$ in the soil are within the exchangeable whereas about $10.43 \%$ of this exchangeable were taken(accumulated) by cassava plants (Equ.2.0). The mobility of $\mathrm{Cu}$ reduced the $\mathrm{Cu}$ in the absorbable state to $1 \%$ in every $20 \%$ of $\mathrm{Cu}$ in the soil whereas $\mathrm{Pb}$ which is less mobile results to $1 \%$ availability in every $4 \%$ of $\mathrm{Pb}$ in the soil (fig.4.0 and fig.5.0). The accumulation of bioavailable heavy metals in farm lands obviously results to much problems to plants, organisms habitat and agricultural productivity as well.

Plant $\mathrm{Cu} \quad * 100 \%$

Bioavailable(Exchangeable+ Reducible)

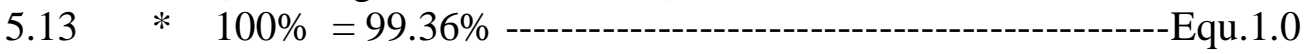

5.163

Plant $\mathrm{Pb} \quad * 100 \%$

Bioavailable (Exchangeable)

$9.813 * 100 \%=10.43 \%$

$\overline{94.0604}$

Soil wetness and $\mathrm{Ph}$ are two factors that strongly influence the release of mineral elements to plants. The toxicity of available elements in soil and plants are usually dependent on $\mathrm{Ph}$ hence a toxic element in acidic environment could be non-toxic in a carbonate environment. The ph range in the study area is 4 to 6 which is acidic and can be of negative effect when absorbed by plants and human tissues. The accumulation of the bioavailable heavy metals in farm lands obviously results to much problems to plants, organisms habitat and agricultural productivity in general (Moolenaar et al. 2012).

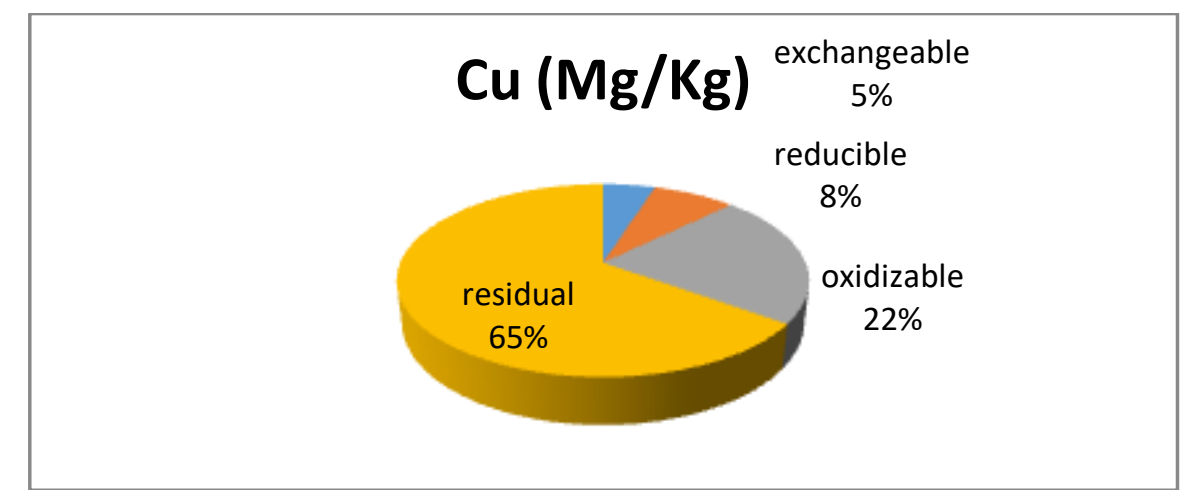

Fig.4.0 Percentage distribution of $\mathrm{Cu}$ in Enyigba-Ameka Farm Land

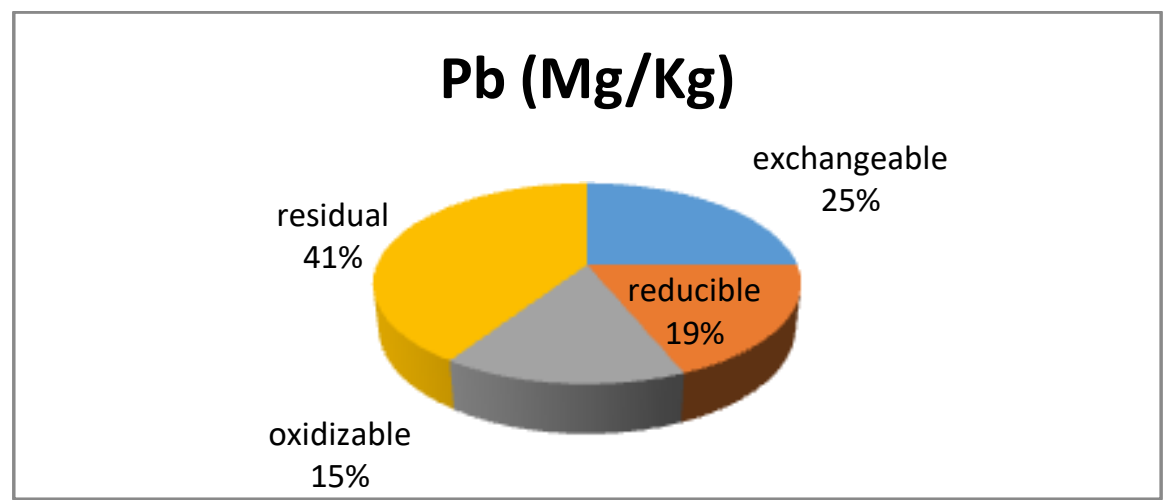

Fig.5.0 Percentage distribution of Pb in Enyigba-Ameka Farm Land 
The distribution chart of (fig 4.0 and fig 5.0) of the farm land soil revealed that the ratio of $\mathrm{Cu}$ and $\mathrm{Pb}$ between the exchangeable to the total heavy metals in the soil is 1:20 and 1:4 respectively.

Table 3.0 Bioavailability and Plant uptake Comparison In soils and Plants

\begin{tabular}{|l|l|l|l|l|}
\hline $\begin{array}{l}\text { Heavy } \\
\text { Metals }\end{array}$ & $\begin{array}{l}\text { Average } \\
\text { exchangeable } \\
\text { fraction in the soil }\end{array}$ & $\begin{array}{l}\text { Plant uptake } \\
\text { cassava } \\
\text { (tuber) }\end{array}$ & $\begin{array}{l}\text { *Acceptable } \\
\text { for unpolluted } \\
\text { soil } \\
(\mathbf{m g} / \mathbf{k g})\end{array}$ & $\begin{array}{l}* * \text { Max.permitted } \\
\text { Limit in } \\
\text { Food/plant } \\
(\mathbf{m g} / \mathbf{k g})\end{array}$ \\
\hline $\mathrm{C}_{\mathrm{u}}$ & $2.004(5 \%)$ & $5.13(99.36 \%)$ & 36 & 10 \\
\hline $\mathrm{Pb}$ & $94.060(25 \%)$ & $\begin{array}{l}9.813 \\
(10.43 \%)\end{array}$ & 85 & 2 \\
\hline
\end{tabular}

*(Ministry of Housing, Netherlands 1994)

** WHO (1996)

In tab.3.0, the available $\mathrm{Cu}$ is less than the acceptable limit for unpolluted soil and same is applicable for the cassava uptake whereas the available $\mathrm{Pb}$ in the biota is beyond the acceptable limit for unpolluted soil. The plant cassava uptake of $\mathrm{Pb}$ is higher than the maximum permitted limit which is $2 \mathrm{mg} / \mathrm{kg}$. It is obvious that both the bioavailable $\mathrm{Pb}$ in the soil and that taken by the tuber plant of cassava is beyond the acceptable limits of both the soil and the tuber plant. This results shows that $\mathrm{Pb}$ exposure is a major source of concern which could result to $\mathrm{Pb}$ poisoning in the area.

\section{Conclusion}

The results showed that the plant uptake/bioaccumulation of heavy metals of $\mathrm{Cu}$ in EnyigbaAmeka is within the exchangeable and reducible sequence of the soil and that the bioavailable $\mathrm{Cu}$ is within the acceptable limit. Whereas the bioavailable $\mathrm{Pb}$ and the tuber accumulated $\mathrm{Pb}$ is beyond the acceptable limit. The comparative study has confirmed that more than one approach is essential in bioavailability studies and that valid pollution studies should include bioavailability since heavy metal not released into the biota does not affect the plants, animals, and man which are the target beneficiaries in the food chain and pollution studies. Finally, $\mathrm{Pb}$ needs to be checkmated and controlled, or could result to lead poisoning in Enyigba-Ameka within a short time span.

\section{References}

1. Blaylock, M. J. and Huang J. W, (2000).Phytoextraction of metals.In: Raskin, I., Ensley, B. D. (Eds.) Phytoremediation of Toxic Metals: Using plants to Clean up environment. John Wiley and sons, New York.p.53-70.

2. Chojnacka, K., Chojnacki, A., Gorecka, H. and Gorecki H. (2004). Bioavailability of heavy metals from polluted soils to plants. Science of the Total Environ.337.p.175182.Elsevier publication.

3. Ezeh, H.N., Anike, O.L., And Egboka, B.C.E. (2007). The distribution of some heavy metals in soils in areas around the derelict enyigba mines and its environmental implication.Current World Enviroment.2(2), 99-106.

4. Kabata-Pendias, A.(2011). Trace Elements in Soils and Plants. Taylor and Francis Group,LLC. Fourth edition. 505pp.

5. Kheboian, C. and Bauer, C.F.(1987). Accuracy of selective extraction procedures for metal speciation in model aquatic sediments. Anal.Chem.,59,1417-1423. 
6. Kim, N.D. and Fergusson, J.E, (1991). Trace elements in Street and House Dusts: Sources and Speciation. Sci. Total Environ. 100:125-150.

7. Mamah, L. I., Ezepue, M. C. and Ezeigbo, H. I., (2000).Integration of geology and geophysics in mineral exploration in the Benue Trough, Nigeria: the Onuahia lead-zinc deposit - a case study. Global J. Pure and Applied Sci. 6, p. $255-262$.

8. Mehra, A., Cordes, K.B., Chopra, S. and Fountain, D. (1999). Distribution and bioavailabilty of metals in soils in the vicinity of copper works in Staffordshire, U.K. Journal ofchemical Speciation and bioavailabilty.11(2): 57-66.

9. Menzies, N. W., Donn M. J., kopittke P. M. (2007). Evaluation of extractants for the estimation of the Phytoavailable trace metals in soils. Environ. Pollut. 145.p.121-130.

10. National Environmental Policy Institute.(2000). Bioavailability: Implications for Science/Cleanup Policy. Bioavailability Policy Project. White Paper.

11. Nnabo, P.N. Orazuike, D.M., and Offor, C.O. (2011). The Preliminary assessment of the level of heavy elements contaminations in stream bed sediments of Enyigba and Environs, South eastern Nigeria. Jour. of basic physical science.2(2). p.43-52.

12. Obasi, P. N. and Akudinobi, B.E.B. (2015). Geology, water types and facie evolution of Ohaozara saline lake areas of Ebonyi state Nigeria.

13. Olayinka, K. O., Oyeyiola A. O., Odujebe F. O, and Oboh, B. (2011). Uptake of potentially toxic metals by vegetable plants grown on contaminated soil and their potential bioavailability using sequential extraction. Jour. of soil sci. and environ. Manag. 2(8). p.220-227.

14. Oyeyiola, A. O., Olayinka, K. O., Alo B.I. (2010). Comparison of three sequential extraction protocols for the fractionation of potentially toxic metals in coastal sediments. Environmental monitoring and assessment D01 10.1007/s10661-010-1336-4.

15. Onyeabor and Nwatarali (2017). Irrigation suitability of surface waters of Enyigba Ebonyi state, southeastern Nigeria. International Journal of Innovative Science,Engr. \& Tech. Vol.4,Issue 9.ISSN(Online) 2348-7968.

16. Thornton, I.(1983). Applied Environmental Geochemistry. Academic Press Series.501pp.

17. Tokalio Glu,S. Kartal, S. And B Irol, G. (2003).Application of a Three-Stage Sequential Extraction Procedure for the Determination of Extractable Metal Contents in Highway Soils. Turk J Chem 27,pp $333-346$.

18. Traina, S. J. \& Laperche, V. (1999) Proc. Natl. Acad. Sci. USA 96. 3365-3371

19. U. S. Navy and Marine Corps Facilities User's Guide.2000.

20. NFESC UG-2041-ENV Guide for Incorporating BioavailabilityAdjustments into Human Health andEcological Risk Assessments.

21. World Health Organisation (1996). Permissible limits of heavy metals in soil and plants .WHO Geneva Swtzerland. 